\title{
Sailing through the waves: Ecclesiological experiences of the Gereja Protestan Maluku archipelago congregations in Maluku
}

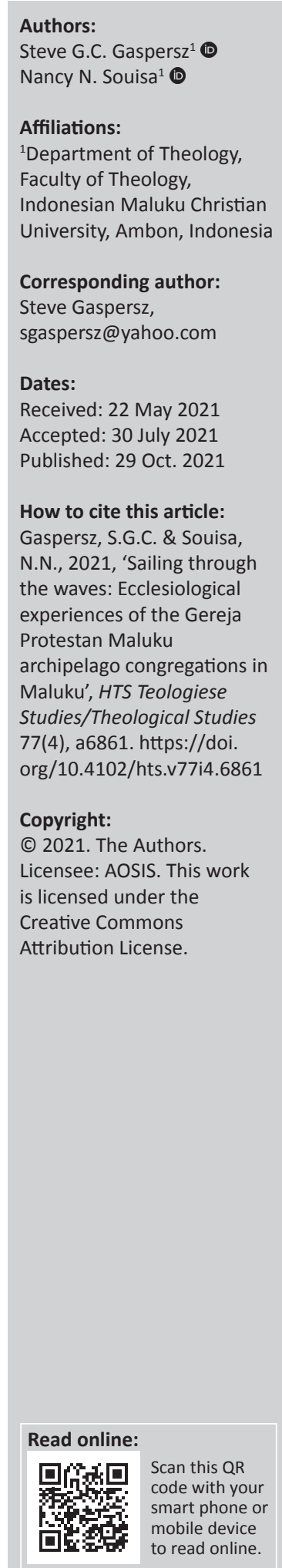

The archipelago context of Maluku represents the living dynamics of Christian communities in that area, which becomes an ecclesiological foundation of the Gereja Protestan Maluku (GPM). Christianity, the embryo of the GPM, is the fruit of the evangelical works by European missionaries, particularly Dutch missions from the 18th century onwards. The Dutch-type Christianity had been adapted into models so that the form of institution and Protestant teachings in Maluku moved dynamically following socio-political and cultural changes along with the colonial and the post-colonial history of Indonesian and Malukan society. It attempts to describe the manifestation of the Calvinism-model of Christianity that is continuously being contextualised through absorbing various elements of worldview, tradition, and the religiosity of the archipelago society. Cultural hermeneutics is used to interpret the socio-cultural phenomena in which the church lives in and to construct its theological understanding about Christian identity. The ecclesiological construction of GPM, in turn, is structured by plural social orders. The reality also influences the perspective about GPM from many different worldviews of the Malukan archipelago society. The contextual ecclesiological perspective, therefore, is constructed based on intermingled understandings that theology of the church can only be built by considering multifold dimensions of a particular society. The result of this research pertains to the constructive understanding of a specific ecclesial context of the GPM in their struggles for theologising their existence as God's people and, at the same time, as an integral part of certain society in Maluku and Indonesia.

Contribution: As the living contextual church that struggles for proclaiming God's love, the GPM has a theological responsibility to conduct its church mission based on its ecclesiological understanding and practices contextually. The article contributes to the enrichment of the theological discourse on the crucial roles of a church in Maluku, in the eastern part of Indonesia.

Keywords: contextual ecclesiology; political identity; archipelago congregations; maritime culture; public theology.

\section{Introduction}

This article is an effort to scrutinise the way one particular church in eastern Indonesia, namely the Protestant Church of Maluku (Gereja Protestan Maluku [GPM]), is constructing its ecclesiological identity in the political context of Indonesia, the country with the largest Muslim population in Southeast Asia, as well as understanding its theological dimensions as an integral part of the cultural context of an archipelago society. This theological investigation is framed by a contextual theological paradigm to discover people's cultural viewpoints and their theological reflection as the dialectic way to comprehend their identity as a Reformed-based congregation of GPM as well as a Christian community, which lives in the specific archipelago context of Indonesia.

Ecclesiology might be comprehended as the church's way to see its existential mission and function as well as its participation along with different other faith communities. It means that the church should be understood in its existential meaning and contextual praxis. Without those articulations, the church's discourse and practice of being a manifestation of ecclesiological substance will only be caught by an awkward perspective, and at the same time, undermining its historical, sociological, political, and anthropological roots. The church, hence, must be seen both as an organism and organisation. As the former, the church implies there is movement, growth, and change; as the latter, the church demonstrates its pluralistic posture that needs a distinct method for organising its different organs and managing its existential and functional relations with others. 
The Greek word ecclesia shows cultural dimensions with the existential axis on progressive interaction and responses toward its pluralistic circumstance. The ecclesiological discourses are moving dynamically in the public arena where humanity discovers interconnectivity, clashes, segregation and integration with reflection and praxis in its living context (Van der Ven 1993:87-93). Therefore, the effort of tracing the GPM's ecclesiological footprints might place the entity of the Christian community in the Maluku archipelago as a theological subject which, in its historical trajectory from the past to its theological construction today, continuously gives a contextual meaning of the ecclesia itself.

\section{Method}

This article is based on two research methods, namely: (1) anthropological research and (2) theological inquiry. Anthropological research was conducted by implementing ethnographic observation to understand cultural elements that construct ecclesial perspectives of Christians in Maluku. It was also supported by huge collections of empirical data by previous anthropologists or sociologists in the Maluku archipelago, such as Cooley, Bartels, Ellen, Laksono, Soselissa, and so on. Meanwhile, theological inquiry was conducted by interpreting anthropological data, analysing the symbolic cultural meaning in which the indigenous people in Maluku related them to Christian faith, and examining the living experiences of the Christians who live in the archipelago context as the main resources for constructing the ecclesiology of GPM contextually.

\section{Conceptual framework}

Sibak ombak and toma arus are two common phrases in the daily conversations of the Malukan archipelago society, which mean 'sailing through the sea waves'. These phrases reflect the inner feeling of the interconnectedness of people with the sea. At the same time, they also show the distance between human beings and their circumstances (sea and islands). All activities are related to the coastal area, sea, and islands so that it is a kind of existentially closed relationship that forms the worldview of the archipelago society. The sea brings about an existential distance as a contextual challenge that needs to be considered by the archipelago society. Musim Timur (east season) and Musim Barat (west season) are the determinant natural factors in carrying out many activities in the land and sailing on the sea. The consideration of the eastwest seasons constitutes geographical distance because the sea has its energy that cannot be subdued by human beings.

These phrases also reflect the historical and sociological realities of the archipelago context which characterises the dynamics of Christian lives that should become a foundation of the GPM ecclesiology, displaying contextual, vulnerable, and conflictual challenges. The historical and sociological realities might be seen in the formulation of the GPM's motto (1 Cor 3:6), which briefly does not touch the sea-island reality as the basic fact of its ecclesiology since its establishment in 1935.
The institutional forms and teachings of Protestantism have been contextualised dynamically following the socio-political and cultural changes that have taken place throughout the post-colonial history in Maluku (De Jong 2012:1-21). The Calvinistic Protestantism in Maluku has developed through a dynamic contextualisation process with the absorption of various elements of worldviews, traditions and religiosity of the local communities, and by the awareness of the reality that Islam is also growing in the archipelago context of Central Maluku.

The ecclesiological construction of the GPM is, in turn, composed of multiple social settings. This reality also influences the perspective about the GPM from various worldviews of the Maluku archipelago community. The nuance of identity politics has become an integral part of the discourse of church life in Maluku. The orientation of identity politics generally surfaces when there is a feeling of dissatisfaction towards the dominance of certain ethnic groups in the GPM's structure, which is considered as giving privilege to certain ethnic groups and, at the same time, marginalising others. This orientation is regarded as a legacy of colonial mentality that gave privileges and facilities particularly to ethnic groups of the Ambon-Lease Islands. They enjoyed the greater opportunities to receive higher education and social status as colonial civil servants. Meanwhile, the remote south-eastern islands experienced a much marginalised situation. The centre-periphery dichotomy was strongly felt in the ecclesiological construct of the GPM throughout the New Order (1966-1998) (Titaley [2015] in Gaspersz et al. [eds. 2015]:55-63).

The context of congregations who are living on hundreds of islands is a potential for great internal conflict and produces a high degree of complexity in the management of the GPM organisation (GPM Synod [Sekretariat Umum Sinode Gereja Protestan Maluku] 2016). However, the context of scattered and numerous islands has encouraged GPM to apply ecclesiological strategies to systematically strengthen consolidation of the church. All efforts to consolidate the institution have high-cost financial consequences (Maspaitella 2019). Such an archipelago context produces an image of the church that spends most of its energy on managing the institutional matters and strongly emphasises church order rather than strengthening its spirituality.

\section{Toward an inclusive ecclesiology}

Historically, Knaap (1991) reported that Ambon is a city of migrants, which has confirmed the pluralistic reality inherent in the dynamics of Ambonese society. Before the arrival of the Europeans, the Ambonese made economic transactions with foreign traders, even beyond the area that is now known as Southeast Asia. The Europeans then became part of the complexity of Ambonese society, which led eventually to the unequal social relationships between Europeans and nonEuropeans. The posture of Christianity in Ambon was demonstrating hybrid identity so that it was vulnerable to potential friction and identity politics. Relations between 
Christian and Muslim communities in Ambon since the colonial period were strongly determined by the Dutch political policy (Chauvel 1990:161). The long period of unequal relations experienced a turning point and deconstructed the religious identification process during the short, but significant, period of Japanese military occupation.

In the context of local culture, Ambonese Muslim-Christian (Salam-Sarane) relations are still connected through the bonds of pela and gandong brotherhood. Pela is a cultural pact between two or more communities in Maluku, either with the same or different religious affiliations. Pela ties are solidified after experiencing a significant event together in inter-community relationships (Bartels 1977, 2017). Whereas, gandong [womb] relations are more existential because they are confirmed through mythological recognition that those sibling communities (same and/or different religious backgrounds) have biological sibling relations but because of certain events were separated and the communities moved to live on different islands. The myths were treated and ritualised as a form of a historical collective memory by later generations (Gaspersz 2016:80).

The politics of uniformity was implanted by the New Order regime through the issuance of Decree No. 5/1979 about the restricted local administration system by preferring the Javanese village administration (Topatimasang 2004). Since the Reformation Movement in 1998, local autonomy created an ambiguous authority and multiple interpretations of culture that, to a certain extent, triggered social disputes and intercommunity conflicts (eds. Nordholt \& Van Klinken 2007:11-15).

The politics of uniformity at the village level in Ambon destructed the relations between the two authorities. One community is governed by two different authorities: bapa raja [village head] and pendeta [priest]. Cooley (1987:372-374) assumed that this situation was a conflict of authority and a functional dichotomy between gospel and culture. The hybridisation of local culture and Protestantism has given rise to a new model of Christianity in Maluku. In that cultural reality, pela-gandong function as social glue to reduce the potential communal conflict internally and externally (Ruhulessin 2005:275).

The complexity of the archipelago's socio-cultural reality challenges the GPM to extend her ecclesiological insights not only on the axiom Gereja Orang Basudara (brotherhood church - GOB) but more on the Gereja Bagi Semesta (church for the universe or an inclusive church - GBS). The axiom GOB is not sufficient to serve as the ecclesiological foothold of GPM even though it has been spread around for the past two years by the synod officials. The idea of GOB was promoted by Rev. Ates Werinussa, the chairperson of the GPM Synod ([Sekretariat Umum Sinode Gereja Protestan Maluku 2016] 2015-2020). ${ }^{1}$

1.Oral presentation by the chairperson of the GPM Synod Board, Rev. A. J. S Werinussa, in the National Christian Youth Camp of the Indonesian Protestant Werinussa, in the National Christian Youth Camp of the Indonesian Protestant
Church 2017 in Airlouw Congregation, Ambon Island. Link: https://www.youtube. com/watch?v=zwDiy5yMyz8 (0:19-1:21).
However, the connotation of orang basudara reflects a translation of socio-cultural relationships within pela-gandong as primordial bonds of Maluku indigenous community, especially among Salam-Sarane. It has no sufficient epistemic space to accommodate the complexity of socio-cultural plurality in contemporary Maluku society, which is composed of a multi-layered primordial identity (ethnicity and religion). It is not very flexible in absorbing the dynamics of global community encounters as an implication of the increasing development of transportation facilities and communication technologies that bring down the ideological and geographical barriers of global communities.

The universal perspective of the GPM's ecclesiology encourages critical viewpoints and ways to act more on understanding rather than judging - a shared reality of self-in-relation-withother or relational faith. It is no longer in the subject-object dichotomic trap. The authors agree with Hovorun (2015) who offered a phenomenological perspective in the attempt to overcome the neo-Kantian subject-object dilemma:

This method helps the church to avoid the trap of the subjectobject binary because the self-perceiving church should not be understood in terms of subject-object. On the one hand, the church is simultaneously a subject and an object of cognition. On the other hand, it is neither a subject nor an object, because there is no distinct subject or object of the church apart from its members... The church is more than it thinks of itself. (p. 157)

In such issues, GBS is not only standing upon an anthropocentric paradigm but situating human beings and humanity within the existential and cosmological relationship with the world-place-of-living-together-with-other. The GPM fully engages in global struggles such as the global ecumenical movement, the challenges of natural disasters, the environmental devastation exacerbated by certain development issues in island ecosystems, human trafficking, structural impoverishment in island communities, inequality of education and employment opportunities, and being vulnerable to the exploitation of transnational capitalism.

\section{Divided sea, calm sea}

The sea and islands are always seen dialectically as a reality of openness to good possibilities as well as challenges (sea) and life (islands). Although most of the Maluku island communities live in the coastal areas, sociologically their cultural characteristics are closer to coastal communities. One prominent feature is the dialectic of the sea and land orientation, as reflected in the expression of everyday terms to indicate directions: ka lao / ka dara [towards the sea / towards the land] or pi pante/pi gunong [go to the beach / go to the mountain].

In Maluku cosmology, the sea is not terra nullius, but spiritually they believe that it has a 'name', as I (Steve Gaspersz) learned during my personal experience when conducting inter-island voyages by motorboat. Once, when we faced a storm and big waves, certain passengers on those boats knew the name of the sea. Usually, they stood on the boat's bow, and for some minutes they muttered as if saying something to the 
thunderous sea. Although the sea did not immediately calm down, the tanase [helmsman] could sense that the waves were no longer a threat, saying, 'the waves accompany us'. Getting to know the sea's name means being friends with the sea. It is not merely an object, but together with human beings, is a living subject as part of God's creation.

Among coastal congregations in Maluku, the story of Jesus calming the sea is better understood as his friendship with the sea (as part of the cosmos) because he knows the sea's name. There are many other similar stories related to the sea showing that the relationship between human beings and the sea is not a kind of subject-object relationship but an existential one between the world of humans on land and the world of aquatic creatures in the sea.

The sea is a field of energy that is so powerful that humans need the ability to 'read' its signs. They call such natural interpretations tanuar, which is the ability to read natural phenomena like winds and waves to decide what actions to take - to set sail or to anchor. Tanuar is a soft skill that is acquired through many years of experience interacting with nature. These principles are taught and handed down from parents to their children. This term therefore has semantic accretion as the ability to interpret the phenomenon of the cosmos (human and nature) as a complete relational manifestation of all elements in the universe. This shapes the worldview and the cosmology of coastal communities, as well as being an existential foothold of religiosity.

However, the contextual perspective of Maluku coastal communities about the sea has an asymmetrical position against a textual perspective in the Bible. In the biblical narratives, especially the Hebrew Bible, the sea has:

' $[A]$ strong sense of creaturely vulnerability, fear of this dangerous aspect of God's creation and awe at his mastery of it precludes any thought of seeking to manipulate this environment.' (Watson [2019] in Hunt \& Marlow [eds. 2019]:92)

A strong orientation to land does not provide adequate space in understanding the sea, so the traditions of interpreting the biblical texts avoid interpreting the sea as part of the positive realm, even as a source, for doing theology of church (ecclesiology). One contemporary example is a popular Sunday school song whose lyrics are as follows:

Yesus angkat dosaku dan buang ke laut ... byuur

Aku bahagia, bahagia, karena Tuhan Yesus angkat dosaku

Jesus lifted my sin and threw it into the sea ... splash!

I am happy, happy because the Lord Jesus lifted my sin

The lyrics show the Christian negative theological perspective about the sea. The sea is seen as a place to dispose of sins. The fatal implication of such understanding is that one may throw everything into the sea. It is in contrast to the worldview of coastal communities who comprehend the sea precisely as the arena of life, and therefore the pattern of their settlement generally faces the sea, not away from the sea.
From the sea comes life and others (guests) who must be welcomed, not 'put behind'.

This is different from the contextual song's lyrics that reflects a sort of living perspective about the Maluku island communities.
Di tengah ombak dan arus pencobaan, hampir terhilang tujuan arah hidupku
Bagaikan kapal yang slalu diombang-ambingkan
Berharap kasih-Nya seolah-olah tiada mampu
Yesus perhatikan kehidupan stiap orang
Dia mengenal hatimu yang penuh penyesalan dosa
Amid sea storm and the flow of temptation, almost lost the purpose of my life
Like a boat that is always tossed around
Expect God's love as if it is incapable
Jesus notices everyone's lives
He knows your regretful heart

The original lyrics of the song are about the tragedy of the motorboat 'Oni' which was overloaded with passengers on its way from Ambon Island to Saparua Island on Christmas Eve. It sank after being hit by big waves, and all the passengers drowned and were lost at sea. The tragedy was enshrined as a collective memory through a folk song. Some local musicians then changed the folk song into a spiritual song through which they reflect the analogy of human life like a boat amid thunderous sea, but there is still the power of hope for God's love to guard the believers. This song is well known among the Ambonese Christians because it touches on their existential dimension as the people who befriend and grapple with the reality of the sea in Maluku.

Theological interpretations about the sea as an arena to struggle and experience the divine mystery in the reality of humanity are born from the contextual reality of archipelago communities. This kind of theological interpretation is a creative form of the dialectics of context and text (Bible). At the same time, it is a deconstruction of the biblical text which exposes the sea as a dark territory and hopelessness, even terra nullius. On the contrary, the theological interpretation by the archipelago Ambonese Christians strongly conveys a message that the sea is the arena of encounters with various possibilities of life and death. It involves the theological dialectics which increasingly weighs on the meaning of hope - the hope of life as well as the hope of death. Both are united in marine cosmology. Hope does not end in a happy ending (physical safety), but is also faced as an estuary of death dying with the hope for God's eschatological salvific acts.

The sea is also a kintal [front yard] where others are received as his or her family members, and becomes part of his or her existence, so that all of their otherness is entirely accepted as an integral part of him- or herself or the community as a whole. Openness is the face of the sea, which must be shown in hospitality to accept others into their own lives. 
The 'divided sea' in the story where Moses and the Israelites crossed the Red Sea reflects the revelation of the divine mystery that can only occur under the power of God. The event might be interpreted metaphorically that the sea is not a barrier to the liberation process of the Israelites from Egypt but rather a 'gate' that allows them to pass to freedom from the slavery under the Pharaoh's reign. The sea is a liminal arena that confronts Moses and the Israelites to determine existential living choices between gaining their liberation or remaining in the shackles of colonialism. The sea opens the way to the realm of liberation. This story shows the deconstruction of the cosmological perspective about the sea which is always considered negatively in the worldview of the wilderness nomad community. It also shows the sea as a medium of liberation not only from the colonial situation but also from the structure of colonised mentality, which made it difficult for the Israelites to think and act as 'free people'.

The story about Jesus quietening the ferocious sea seems to adopt and modify the narrative of the divided sea in the Old Testament. This was such a situation that made his disciples tremble with fear. It sounds strange when considering the fact that the disciples were mostly fishermen. The emphasis of the story does not seem to be the ability of Jesus to calm the waves but the anguish of his disciples because at that moment he slept in the stern of the boat as if nothing were happening. The sea, which is considered a 'friend' and 'source of life' by the disciples/fishermen, demonstrated a mysterious and threatening ultimate power. Jesus not only calmed the sea but also reduced the anxiety of his disciples who assumed that they were familiar with the sea, although they were not at all. They were indeed fishermen but disabled to explore the mysteries of the sea power. Jesus calmed the sea because there is an existential correlation between divine power and the mystery of sea power. For the people of Maluku, it is always believed that in this story Jesus knew the name of the sea. Conversely, the sea also recognises the divine voice in Jesus' rebuke.

\section{Developing the archipelago church}

As an integral part of Indonesia after its Proclamation of Independence on August 17, 1945, the GPM merged into an agreement of becoming Indonesia with all the baggage of socio-political-cultural-religious pluralism tied as a geopolitical entity. Although the cross-identity encounter is not a new phenomenon in Maluku social history, the post-independence socio-political construction provides a new frame of discourse that has never happened before.

The issues on multiculturalism that were previously accepted as everyday life practices and common sense in social reality are now undergoing a metamorphosis into structured elements as social and cultural capitals that move political machinery, that is, the state. Differences and pluralism are no longer just social normality but can be easily switched or diverted into ideological devices, which paralyse social reasoning against such plural reality (eds. Gaspersz et al. 2015:55).
A friend of mine, Rev. Bobby Parinussa, who serves as GPM priest in Lirang, Wetar Island, one of the southeastern islands, the frontier island on the Indonesian border with the State of Timor Leste, wrote a gloomy post on his Facebook wall:

'A fisherman from Lirang Island says, 'Indonesia is in our hearts, Garuda Pancasila is on our chest. But our belly is in Timor Leste'. It is the reality on Lirang Island, one island around the Wetar Besar Island, Southwest Maluku Regency. Overnight the fishermen can get 60 to $70 \mathrm{~kg}$ of fish. Lack of facilities and situated in the remote area make local fishersmen are unable to sell their catch in their own country Indonesia. Timor Leste is the only closest potential market to sell their fishes. With a boat powered by a $40 \mathrm{HP}$ engine, they take three hours to get to Dili. In Dili, they sell fish to traders with a price of IDR [Indonesian rupiah] $30000 / \mathrm{kg}$ in Australian dollars; then exchanged to Indonesian Rupiah. I suspect the price is too low. If we want to calculate the types of fish sold it is a very high economic value. Prices are determined by the market in Timor Leste. For the fishermen, the most crucial thing is to be sold out and can get some money for their families at home. We hope that Lirang Island will not just be a 'sweetener' during political campaigns for the local/national election. Hopefully development can be sustained especially in the effort to improve the welfare of fishermen, with easy access to sell fish in their own country: Indonesia.'

The imposition of such development discourse on a centreperiphery paradigm has also determined the construction of an ecclesiological perspective and praxis of Indonesian archipelago churches such as the GPM. The term 'development' is mostly understood by the marginalised indigenous people as exclusion and conquest as reflected in terms such as isolated communities, inaccessible areas, and backward islands (blakang tanah). The church is also hegemonised by pejorative terms in the church management stewardship, such as the dichotomic expressions: jemaat air-mata [tears congregation]/jemaat mata-air [spring congregation]; jemaat basah [wet/rich congregation]/jemaat kering [poor/dry congregation]; jemaat maju [developed congregation]/jemaat blakang tana [underdeveloped congregation] (Gaspersz \& Souisa 2020:16-32).

The transformation of the development paradigm from continental to the archipelago as driven by the spirit of the political reformation of 1998 by the demands for regional autonomy has opened up new perspectives on fair development management for regions considered periphery by the previous government regime. Some island-based development strategies and marine products management are being compiled to stimulate the dynamic of development, especially in the eastern islands of Indonesia (Gaspersz, Souisa \& Nanuru 2018). The context of Indonesian development and socio-political changes becomes a trigger for GPM to rethink the sea-island geographical context as a contextual foundation of its ecclesiological construction. Church development is framed by the pattern of 'centralized vision and decentralized initiatives' articulated through the Pola Induk Pelayanan/Rencana Induk Pengembangan Pelayanan (PIP/RIPP) or Church's Master Model and Master 
Plan for Developing Church Ministry that consists of 13 strategic issues (Badan Penelitian dan Pengembangan Balitbang GPM 2016-2025 [2015]):

1. Developing Church Formal Education and Church Member Education.

2. Capacity Building for the Church Ministers.

3. Strengthening and Development of Family-Based Spiritual Resilience.

4. Strengthening and Development of Church InterDenominational Relations.

5. Environmental Management and Natural Disaster Management.

6. Poverty Management and Empowering People's Economic Resilience.

7. Overcoming HIV-AIDS Endemic and Other Health Problems.

8. Developing Inter-Faith Dialogue and Cooperation.

9. Strengthening the Church's Political Role for Humanity and Social Justice.

10. Developing Support Systems to Strengthen Basic, Secondary and Higher Education.

11. Developing Information, Documentation and Communication Capacity for Church Ministry.

12. Management of Church Property.

13. Constructing Effective and Sustainable Institutional Management.

These issues are fragments of reality that are reflected by the GPM in its socio-historical journey to build a contextual ecclesiology in responding to the problematic humanitarian situation of its congregations. These issues are presented as consequences of the reality of the church in eastern Indonesia, which since the colonial period to post-colonial Indonesia has faced problems of injustice by various political development policies in Indonesia. Therefore, these issues reflect the existential struggle of an archipelago church in Indonesia.

\section{Conclusion}

Problem mapping through the implementation of the church's strategic plans is a necessity for the church's development strategy, which is not only emphasising ritualistic activities and internal church management but also a more proportional concern for the reality of inequality of development that they have experienced together with other communities. Criticism of acts of injustice in human development is expected to encourage the GPM to be more sensitive to any development activities that lead to the marginalising of local communities. The pressures of economic life and cultural marginalisation will have a significant impact on plural inter-community relations. So, there is a great possibility for the emergence of social conflict and violence which will break up the peaceful relations between the diverse communities in the archipelago. The GPM continuously lives in the realm of the missiological struggle for universal humanity. The plurality and archipelagic characteristics inherent in it have formed an inclusive, plural and multicultural ecclesiological self-understanding. This ecclesiological content must be sharpened to be sensitive to the reality of pluralism and socio-cultural development for all congregations and the broader society of Indonesia.

\section{Acknowledgements}

We would like to express our gratitude to the GPM church members who were willing to share their knowledge and experiences about contextual understanding on Christian faith. Our deep gratitude is extended to Rev. Elifas Maspaitella, the chairperson of the GPM Synod Board 2021-2025 who shared his theological notions on the GPM's ecclesiology.

\section{Competing interests}

The authors declare that they have no financial or personal relationships that may have inappropriately influenced them in writing this article.

\section{Authors' contributions}

S.G.C.G. and N.N.S. contributed to the writing of this research article.

\section{Ethical considerations}

This article followed all ethical standards for research without direct contact with human or animal subjects.

\section{Funding information}

This research received no specific grant from any funding agency in the public, commercial, or not-for-profit sectors.

\section{Data availability}

Data sharing is not applicable to this article as no new data were created or analysed in this study.

\section{Disclaimer}

The views and opinions expressed in this article are those of the authors and do not necessarily reflect the official policy or position of any affiliated agency of the authors.

\section{References}

Badan Penelitian dan Pengembangan (Balitbang) Gereja Protestan Maluku, 2015, 13 Isu Strategis Pengembangan Pola Induk Pelayanan (PIP) dan Rencana Induk Pengembangan Pelayanan (RIPP) Tahun 2016-2025, Beserta Tujuan, Sasaran dan Indikator, Strategi, Program, Kegiatan \& Indikator dari Setiap Isu Strategis, The GPM Synod Board, Ambon.

Bartels, D., 1977, Guarding the invisible mountain: Intervillage alliances, religious syncretism and ethnic identity among Ambonese Christians and Moslems in the Moluccas, Cornell University, Ithaca, NY.

Bartels, D., 2017, Di Bawah Naungan Gunung Nunusaku: Muslim-Kristen Hidup Berdampingan di Maluku Tengah, Jilid I: Kebudayaan/Jilid 2: Sejarah, Kepustakaan Populer Gramedia, Jakarta.

Chauvel, R., 1990, Nationalists, soldiers and separatists: The Ambonese islands from colonialism to revolt 1880-1950, KITLV Press, Leiden.

Cooley, F.L., 1987, Mimbar dan Tahta: Hubungan Lembaga-lembaga Keagamaan dan Pemerintahan di Maluku Tengah, Pustaka Sinar Harapan, Jakarta.

De Jong, C.G.F., 2012, Sumber-sumber tentang Sejarah Gereja Protestan di Maluku Tengah 1803-1900, Jilid 1: 1803-1854, BPK Gunung Mulia, Jakarta.

Gaspersz, S.G.C., 2009, Teologi Kelautan dalam Konteks Pembangunan Indonesia viewed 25 February 2021, from http://kabaressi.blogspot.com/2009/04/teologikelautan-dalam-konteks.html. 
Gaspersz, S.G.C., Maspaitella, E.T., Takaria, M. \& Marantika, E. (eds.), 2015, Delapan Dekade GPM Menanam, Menyiram, Bertumbuh dan Berbuah: Teologi GPM dalam Praksis Berbangsa dan Bermasyarakat, Satya Wacana University Press \& GPM, Salatiga.

Gaspersz, S.G.C., 2016, Negotiating religious identities, cultural authorities and modernity in Leihitu, Ambon Island, The Indonesian Consortium for Religious Studies [ICRS], Universitas Gadjah Mada, Yogyakarta.

Gaspersz, S.G.C. \& Souisa, N.N., 2020, 'Revitalisasi Tradisi dan Politik Identitas: Dialektika Kristianitas di Maluku', Dialektika: Jurnal Pemikiran Islam dan IImu Sosial 13(2), 16-32.

Gaspersz, S.G.C., Souisa, N.N. \& Nanuru, R.F., 2018, 'The welfare-based development in the context of maritime culture: Encounters with anthropological perspective', in IOP Conference Series: Earth and Environmental Science, vol. 175 , p. 012218 , viewed n.d. from https://iopscience.iop.org/article/10.1088/1755-1315/175/1/012218.

Hovorun, C., 2015, Meta-ecclesiology: Chronicles on church awareness, Palgrave Macmillan, New York, NY.

Hunt, A. \& Hilary, M. (eds.), 2019, Ecology and theology in the ancient world: Crossdisciplinary perspectives, Bloomsbury Academic, London.

Knaap, G.J., 1991, 'A city of migrants: Kota Ambon at the end of the seventeenth century', Indonesia 51, 105-128. https://doi.org/10.2307/3351067
Maspaitella, E.T., 2019, Strategi Pengawasan Perbendaharaan GPM: Perspektif Gerejawi dan Peraturan Gereja, The GPM Synod Board, Ambon.

Nordholt, H.S. \& Van Klinken, G. (eds.), 2007, Renegotiating boundaries: Local politics in post-Suharto Indonesia, Koninklijk Instituut voor Taal-, Land- en Volkenkunde Press, Leiden.

Ruhulessin, J.C., 2005, Etika Publik: Menggali dari Tradisi Pela di Maluku, Satya Wacana Christian University, Salatiga.

Sekretariat Umum Sinode Gereja Protestan Maluku, 2016, Pola Induk Pelayanan dan Rencana Induk Pengembangan Pelayanan (PIP-RIPP) Gereja Protestan Maluku 2015-2025, The GPM Synod Board, Ambon.

Titaley, J., 2015, 'Tantangan Berteologi bagi GPM di Indonesia', in S.G.C. Gaspersz et al. (eds.), Delapan Dekade GPM Menanam, Menyiram, Bertumbuh dan Berbuah: Teologi GPM dalam Praksis Berbangsa dan Bermasyarakat, pp. 55-63, Satya Wacana University Press \& GPM, Salatiga.

Topatimasang, R. (ed.), 2004, Orang-orang Kalah, Insist Press, Yogyakarta.

Van der Ven, J., 1993, Ecclesiology in context, W. B. Eerdmans, Grand Rapids, MI.

Watson, R., 2019, 'Creatures in creation: Human perceptions of the sea in the Hebrew bible in ecological perspective', in A. Hunt \& H. Marlow (eds.), Ecology and theology in the ancient world: Cross-disciplinary perspectives, pp. 91-101, Bloomsbury Academic, London. 